\title{
Performance Evaluation of Basic School Supervisor in Ketapang District, Province of West Kalimantan
}

\author{
Muhammad Khair ${ }^{1}$, M Matin $^{2}$, Eliana Sari $^{3}$ \\ $\left\{\right.$ khair2501@ gmail.com $\left.{ }^{1}\right\}$
}

Universitas Negeri Jakarta, Indonesia

\begin{abstract}
The purpose of the study is to describe and analyze the results of performance of supervisors in: 1) to determine the performance of school supervisors in planning learning to meet the Graduates Competency Standards (SKL), 2) to determine the performance of school supervisors in the functioning of the Learning Implementation Plan (RPP), 3) to determine the performance of school supervisors in providing reinforcement of students' competencies, and 4) to determine the performance of school supervisors in guiding teachers to improve student learning. The research method used is in order to measure performance, which is taken part of Gomes,rating scale, questionnaire, questionnaire with directed choices, critical event techniques, achievement note techniques, level scale associated with behavior, observation, test and observation techniques performance. Respondents were teachers, principals, and supervisors in Ketapang District, totaling 36, 14 and 13 people, respectively.The research results for each objective are: 1) Performance of supervisors in planning learning to meet the Competency Standards of Graduates (SKL) is good enough, 2) Performance of supervisors in enabling the Learning Implementation Plan (RPP) is good, 3) Performance of supervisors in providing competency strengthening learners are good and 4) Performance of supervisors in guiding teachers to improve student learning is good.
\end{abstract}

Keywords: Evaluation of Primary School Supervisor Performance.

\section{Introduction}

School supervisors who in their position as supervisors and facilitators should carry out learning supervision activities to improve the quality of the process and learning outcomes. The activity is oriented towards the learning process carried out by the teacher in the school so that the learning goals and objectives are achieved.

Muslim[1] states that every supervision activity carried out by supervisors contains certain intentions to be achieved. The objectives achieved include improving the quality of learning processes and outcomes. Supervision is carried out so that the educational objectives implemented in schools are the achievement of quality programs. The implementation of the quality program referred to certainly helps the school in carrying out its vision, mission, goals and objectives as mandated in the rules and regulations.

Duties and responsibilities to be continuously carried out so that the educational objectives are achieved, specifically the learning objectives. This opinion is in line with Nurnalisa Z., et al. [2] the main task of the school supervisor is to carry out the supervision function, both academic supervision and managerial supervision. The learning process is related to the attitudes and behavior of students. teachers so they can develop competencies in 
learning. This is confirmed in the Minister of National Education Regulation No. 12 of 2007[3]that the duty of the school supervisor in carrying out academic supervisionincluding: (1) guiding teachers in preparing syllabi; (2) guiding teachers in preparing learning implementation plans (RPP); (3) guiding the teacher in the use of learning methods; (4) guiding teachers in the use of learning media; (5) guiding teachers in utilizing information technology in learning.

Based on the description above, to develop the ability of teachers to carry out quality learning, the performance of school supervisors is needed to guide, and motivate teachers in carrying out learning so that the achievement of learning goals, educational goals, and producing quality students. The supervisor's performance was measured from the coaching and mentoring program for the teacher in carrying out the learning, with the intention of among others to improve the learning process and at the same time improve the teacher's competence in teaching in the school.

The analogy of the performance of school supervisors as referred to in the School Supervisory Standards related to improving quality and the learning process includes the dimensions of: (a) attitudes and behavior in seeking guidance for teachers, (b) having knowledge and skills in conducting and mentoring to teachers, (c) have knowledge and skills to accompany and foster teachers in carrying out learning, (d) have knowledge and skills in evaluating the implementation of learning by the teacher, (e) have the knowledge and skills to conduct research and develop the implementation of learning by the teacher, and (f) have knowledge and communication skills and working with teachers including the community related to the implementation of learning. The behavior of school supervisors is attitude in competence. Furthermore, the performance of school supervisors related to these behaviors is measured, among others, from: (1) the existence of documents regarding criteria and indicators for the success of education and learning in schools; (2) the existence of mentoring activities for teachers, for example, aspects that are important to be assessed in learning, including in each subject; (3) have an assessment instrument regarding the performance of principals and teachers; (4) student learning outcomes for improvement and improvement in the quality of learning; (5) provide reports on the results of supervision to the teacher to improve the quality of learning: and (6) process and analyze data from the assessment of teacher performance in carrying out learning.

Based on the information of the academic supervisor, it seems that it needs to be studied and traced the implementation of academic supervision tasks. The implementation of tasks specifically examined in this study is academic supervision. The performance of academic supervision is assessed is the provision of assistance to teachers in carrying out the learning process. Supervision performance as intended is marked by the implementation of duties and functions in improving the quality of learning.

Researchers consider the importance of academic supervision of primary schools to be studied through scientific research, with the hope that the results can be used as study material to improve the performance of academic supervision, especially in elementary schools. This study examines the quality of the context, input, process and results of implementing the performance of primary school supervisors in Ketapang District. From the results of this study, it will be known and understood about the aspects of implementing the performance of elementary school supervisors so far.

According to Supardi [4]performance is a result that has been achieved by someone in an organization to achieve goals based on standardization or size and time adjusted to the type of work and in accordance with established norms and ethics. While Rachmawati and Daryanto (2013), performance is the level of success of a person or group of people in carrying out their 
duties and responsibilities and the ability to achieve goals and standards that have been set. While Suprihatiningrum [5],confirms performance is the result achieved by someone in carrying out their work according to the size that applies to the work in question. This study focuses on the performance of academic supervision by public elementary school supervisors in Ketapang District, West Kalimantan Province, including planning learning, learning processes, learning evaluation, and activities to improve the competence of school supervisors. The study is related to the assistance and mentor of teachers in improving the quality of the learning process to meet the National Education Standards (SNP).

Academic supervision performance includes: (1) compiling a plan for implementing learning, carrying out teaching and learning activities in the classroom, and evaluating the results of teaching and learning by examining with the correct procedures the abilities and skills of teachers carrying out learning activities; (2) create the situation and conditions implemented the learning process in the classroom by applying effective classroom management techniques by examining the abilities and skills of teachers in managing the class; (3) check andprovide learning guidance to students to be able to obtain optimal development.

Through this research, researchers can find out the true condition of how supervisors perform in carrying out academic supervision tasks. Therefore, it is necessary to conduct research on the Evaluation of the Performance of Supervisors for Primary Schools in Ketapang District, West Kalimantan Province. The sub focus of this research are: 1) Evaluation of the performance of supervisors in planning learning to fulfill SK, 2) Evaluation of supervisor performance in enabling RPP, 3) Evaluation of supervisor performance in strengthening student competencies, and 4) Evaluation of supervisor performance in guiding teachers to improve learners

\section{Method}

This activity is performed on the entire areaadministration of Ketapang Regency, West Kalimantan Province. The research area covers 20 sub-districts in accordance with the work area of the school supervisor. The research was conducted from March 2015 to October 2015.

This research method was carried out using Gomes qualitative research approach[6], namely: 1)rating scale, 2) questionnaire, 3) questionnaire with directional choices, 4) critical event techniques, 5) achievement record techniques, 6) level scales associated with behavior, 7) observation techniques, 8) tests and performance observations. The data is primary through direct sampling from research subjects.

The design of this study uses indicators, descriptors of each indicator that are associated with the standards of the implementation of academic supervision tasks. Indicators are characteristics, characteristics, or signs that indicate the performance evaluation criteria of the academic supervisory duties assessed. The research data set can be accessed in osf.io Open Science Framework.

\section{Results}

Results obtained from observation and research interviews are carried out in the form of records and records to gather information about the performance of school supervisors based 
on academic supervision competencies in order to help teachers develop learning process skills that have an impact on elementary school students learning in Ketapang Regency, West Kalimantan Province, the findings can be described as follows:

1. Performance of supervisors in planning learning to meet Graduates Competency Standards (SKL).

School supervisors play a role in guiding, fostering and assessing teachers in prelearning, core learning activities, mastery of learning material, learning approaches or strategies, and in the utilization of learning resources, expressed in fairly good categories.

2. Performance of supervisors in enabling the Learning Implementation Plan (RPP)

School supervisors guide, foster and assess the teacher in formulating the RPP paying attention to the reference of curriculum operation, drafting RPP, allocating learning time, and formulating RPP. well categorized.

3. Performance of supervisors in providing reinforcement of student competencies

School supervisors guide, foster and assess teachers in learning that triggers and maintains student involvement, assessment of learning processes and outcomes, use of language and technology, and learning closing activities. Declared good category.

4. Performance of supervisors in guiding teachers to improve student learning.

School supervisors guide, foster and assess teachers in construction, implementation and development. well categorized.

\section{Discussion}

Performance of the supervisor of academic supervision will be discussed from research findings based on information gathered through questionnaires, interviews, observations and documentation discussed as follows.

1. Performance of supervisors in planning learning to meet Graduates Competency Standards (SKL)

School supervisors play a role in guiding, fostering and assessing teachers in prelearning, core learning activities, mastery of learning materials, learning approaches or strategies, and in the utilization of learning resources. School supervisors guide teachers in planning learning to meet the Graduates' Competency Standards (SKL) by teachers who are categorized as quite good. Not as expected due to the lack of school supervisors in guiding teachers in planning learning to meet SKL due to the school supervisor's workload related to academic supervision conducted by school supervisors is certainly not effective with the number of target schools exceeding the existing provisions as supardi [4], that performance is the result that has been achieved by someone in an organization to achieve goals based on standardization or size and time adjusted to the type of work and in accordance with established norms and ethics.

However, the existing supervisors make every effort to provide supervision to teachers and principals.Given the heavy task burdened by school supervisors to provide guidance to teachers in schools and lack of supervision in schools with classroom supervision, school supervisors conduct guidance and information through the form of teacher working groups (KKG).

In addition, the graduate competency standard is regulated in the Minister of National Education Regulation No. 23 of 2006, [3] the graduate competency standard is used as an 
assessment guide in determining student graduation. Graduates' Competency Standards are determined by the school with the criteria determined by each school, of course the school still has difficulty in determining the graduation of students. The government, in this case the BSNP, should have graduated provisions by determining criteria for a clear range of values, so that it is easily understood by the school.

2. Performance of supervisors in enabling the Learning Implementation Plan (RPP)

School supervisors guide, foster and assess the teacher in formulating the RPP paying attention to the reference of curriculum operation, drafting RPP, allocating learning time, and formulating RPP. The performance of supervisors in enabling RPP as a basis for the implementation of learning by teachers is stated to be well categorized. This is indicated by the school supervisor guiding the teacher in functioning RPP as the basis for the implementation of learning, most of them have supervised the class especially in terms of the assessment of students which should be filled or assessed by the teacher after the learning process takes place. Most have evaluated the implementation plan of learning by the teacher as a basis for the implementation of learning and learning outcomes are largely in accordance with predetermined standards, so that the supervisor's performance has partially met expectations as said Purwanto [7], that supervision of teaching is supervisory activities that aimed at improving conditions both personnel and material that enable the creation of a better teaching and learning situation in order to achieve educational goals. Thus, considering that most school supervisors have been coaching and guiding teachers in schools, the school supervisor conducts guidance and information on guiding teachers to improve student learning through the form of a teacher working group (KKG).

3. Performance of supervisors in providing reinforcement of students' competencies

School supervisors guide, foster and assess teachers in learning that triggers and nurturesstudent involvement, assessment of learning processes and outcomes, use of language and technology, and learning closing activities are categorized as good. Most school supervisors have guided teachers in strengthening the competencies of students, most supervisors have guided teachers in determining the minimum completeness criteria determined by each school in developing the potential of students. So that most of the students who have reached the KKM certainly do the remedial teacher to complete the learning. This is in accordance with Harris's opinion[8] (2008: 18)teaching supervision is everything that school personnel do to maintain or change what the school does in a way that directly influences the teaching and learning process in an effort to improve student learning.

Thus, given the heavy workload carried out by school supervisors to provide guidance to teachers in schools in determining the Minimum Passing Criteria (KKM) and conducting training in schools with classroom supervision, the effort is to provide guidance and information on how to determine the KKM through the form of teacher working groups (KKG)

4. Performance of supervisors in guiding teachers to improve student learning.

School supervisors guide, foster and assess teachers in construction, implementation and development. The performance of school supervisors in guiding teachers to improve students' learning is good. The success of most supervisors in guiding teachers to improve student learning is due to the majority of supervisors with an S1 education background, so that supervisors understand about their duties and functions as school supervisors, so that guiding teachers to improve student learning has been carried out. This is the performance of school supervisors as expected as stated by Sagala, [9] that 
academic supervision is the focus is reviewing, evaluating, improving, improving, and developing the quality of teaching and learning activities conducted by teachers through a guidance and consultation approach in a professional dialogue atmosphere . Thus, given the heavy workload of school supervisors to guide and guide teachers in schools, school supervisors provide guidance and information on guiding teachers to improve student learning through the form of teacher working groups (KKG).

\section{Conclusions}

The performance of supervisors in planning learning to meet the Graduates Competency Standards (SKL) in Ketapang District can be concluded that the performance of supervisors is quite good.These results are consistent with Gibson's theory, et al.[10] which states that performance is influenced by organizational variables, which consist of resources, leadership, rewards, and structure. Besides that it is influenced by psychological variables, consisting of, perception, attitude, personality, learning, and motivation.

The performance of school supervisors in functioning the Learning Implementation Plan (RPP) in Ketapang District concluded that the performance of supervisors in good category, Supervisor performance had guided teachers in paying attention to the diversity of potential students, so that the effectiveness and objectives of the learning process carried out in .

The performance of school supervisors in strengthening the competencies of students in Ketapang Regencygood category. The supervisor's performance has maximally guided the teacher in paying attention to the diversity of potential students, so that the effectiveness and objectives of the learning process carried out in elementary schools are in accordance with Harris's opinion of supervision of teaching is everything that school personnel do to maintain or change what the school does in a direct way influence the teaching and learning process in an effort to improve student learning processes.

The performance of academic supervision of school supervisors in guiding teachers to improve the learning of students in Ketapang Regency is categorized as good. This is marked by supervisors who have supervised the quality of the learning process.

\section{References}

[1] S. B. Muslim, "Supervisi Pendidikan Meningkatkan Kualitas Profesionalisme Guru." Bandung: Alfabeta, 2013.

[2] Universitas Syiah Kuala, "Electronic Theses and Diseertation (ETD)," http://etd.unsyiah.ac.id/ index.php? $\mathrm{p}=$ show_detail\&id=7779, 2018. .

[3] Kementerian Pendidikan Nasional, Standar Pengawas Sekolah/Madrasah. Kementerian Pendidikan Nasional, 2007.

[4] supardi, "Kinerja Guru." Raja Grafindo Persada, 2013.

[5] J. Suprihatinungrum, "Guru Profesional Pedoman Kinerja, Kualifikasi \& Kompetensi Guru." Jogjakarta: Ar-Ruzz Media, 2013.

[6] Gomes. Faustino Cardoso, Manajemen Sumber Daya Manusia. Yogyakarta: Andi Offset, 2003.

[7] M. N. Purwanto, Administrasi dan Supervisi Pendidikan. Remaja Rosdakarya, 2009.

[8] Portalgaruda.Org, "Download," http://download.portalgaruda.org/article.php?article, 2017. .

[9] S. Sagala, "Supervisi Pembelajaran dalam Profesi Pendidikan." Bandung : Alfabeta, 2012.

[10] Gibson et.al, Organizations, Behavior, Structure, Processes, Twelfth Edition. New Yprk: McGrow Hill, 2017. 